\title{
Ny litteratur om 1864
}

\author{
Af Knud A. Rasmussen.
}

„Det har været et langt sørgeår for Danmark siden den 15. nov. 1863, da Kong Frederik 7. gik til sine fædre, til 25. nov. 1864, da tyskerne forlod Jylland efter at have tilranet sig $2 / 5$ af det gamle Danmarks rige på en så nederdrægtig og lumsk måde, at Europas statsretter ikke let vil finde magen dertil i det første halve seculum,“ skrev proprietær Chr. Jensen Wyff, „Poulinesminde“, Vonsild, i sin dagbog den 27 . nov. 1864.

Hundrede år senere, ved den danske stats officielle mindefest i skanserne på Dybbøl banke 18. april 1964, kunne den danske statsminister fastslå, at vel var sårene fra den gang lægt, men arrene er blevet tilbage, og dem bliver vi aldrig kvit. De skaber erindring.

Et udtryk herfor er den omfattende litteratur, der blev publiceret i løbet af det sekel, som fulgte efter det skæbnesvangre år, der forløb mellem Christian 9.s udråbelse til konge 16. nov. 1863 og ratificationen af fredsslutningen $i$ Wien årsdagen efter.

Alligevel gav hundredårets mindedage en anselig tilvækst af artikler og bøger af forskellig slags, hvori forudsætninger, begivenheder og ikke mindst følgerne, sådan som vi i dag kan overskue dem, blev gennemgået på ny. Det huskede er blevet bragt på afstand, er for os blevet til vedkommende erindring med erkendelsens mulighed $i$ sig.

Nederlaget i 1864, der konfronterede os med en brutal virkelighed, havde som bitreste følge af helstatens fald sønderdelingen af den danske nationalitet. 200.000 dansktalende sønderjyder blev adskilt fra et Danmark, der nu kun omfattede ca. $39.000 \mathrm{~km}^{2}$ med en befolkning på 1,7 mill., tilsyneladende skadet til livsnerven. Sådan fuldbyrdedes da udviklingen fra helstatsmonarki til nationalstat. Tvedelingen af det danske folk skabte dog i brede kredse $i$ den danske befolkning en sønderjysk bevidsthed, som er leven- 
de til denne dag. Nærværende årbøger er et eksempel herpå. ${ }^{1}$ Vel måtte i 1914 50-året for de ulykkelige hændelser mindes i skyggen af et Tyskland på magtens tinde, men dog kunne man glæde sig over, at de danskes rækker $\mathrm{i}$ det fremmede trods hårdhændet prøjsisk undertrykkelsespolitik stod ubrudte, og genforeningsårets glæde blev kun formindsket af tanken om de danske i Flensborg og Mellemslesvig, som måtte blive uden for rigets port og fortsat friste en ublid skæbne, da Tyskland på ny betrådte magtpolitikkens vej. Men de blev ikke glemt, og 2. verdenskrigs resultat, som skaffede Tyskland svære folkelige problemer og skabte nye konstellationer i den store politik, gav danske syd for Skelbækken nye muligheder for dansk livsudfoldelse.

Begivenhederne for hundrede år siden gav i 1963-64 som ventet anledning til en fylde af møder, artikler og beretninger $i$ aviser og tidsskrifter, udstillinger, reportager $i$ radio og fjernsyn, ligesom filmatiseringen af Herman Bangs „Tine“ fortjener at blive nævnt i denne forbindelse. Sammenfattende blev det til fortællingen om, hvordan et folk overvinder et nederlag.

Denne artikel er et forsøg på at give en oversigt over den nye litteratur om 1864. Blandt den litteratur, som er blevet udgivet $i$ mindeåret, er „intet større værk, som på afgørende måde ændrer billedet af krigens militære gang eller de diplomatiske forhandlinger før krigen eller $i$ skæbneåret 1864. “2 Forskningen indstiller sig ikke efter mindeår, og $\mathrm{i}$ de senere årtier er en række grundige studier, såvel over hændelsesforløbet $\mathrm{i}$ krigen som de diplomatiske forhandlinger før denne, blevet publiceret. ${ }^{3}$ Man kan vist $i$ det hele næppe regne med, at der blandt det materiale, som fremtiden endnu måtte kunne fremdrage og stille til rådighed for forskningen, vil være væsentligt nyt at finde. Et hundredårs forsken har sigtet stoffets mangfoldighed, så det væsentlige og afgørende har fundet sin rette plads i hændelsesmønstret. Tilbage står allerhøjst detailjusteringer.

Klare og saglige, og i formen populær i dette ords bedste betydning, er Troels Finks „Otte foredrag om Danmarks krise 186364", som i løbet af vinteren 1963-64 blev holdt i radioen. Heldigvis kom de senere $\mathrm{i}$ bogform. Forfatteren, der tidligere har publiceret banebrydende arbejder om dansk udenrigspolitik $\mathrm{i}$ årene for og efter århundredskiftet, giver i den nævnte fremstilling en 


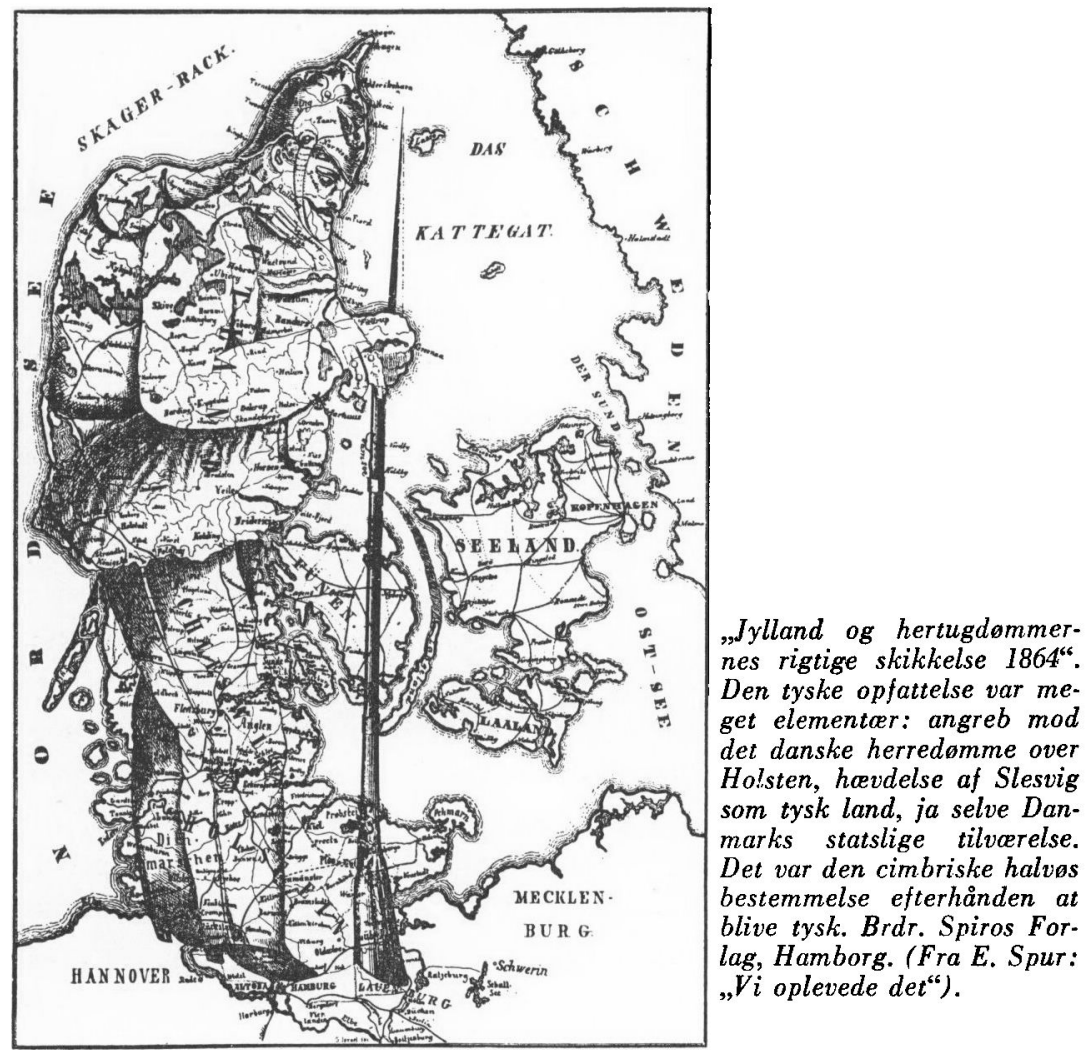

oversigt over de politiske begivenheder, som førte til det resultat, der blev den afgørende forudsætning for dansk udenrigspolitik frem til 1920. Emnet belyses fra et dansk, nordisk, prøjsisk og europæisk standpunkt. Indholdet er resultatet af egen forskning $i$ et vidtløftigt stof. At fremstillingen er kort, betyder langt fra overfladisk. Formen afslører ikke blot en dygtig fortæller, men også en pædagog. Det er mennesker, der er de væsentlige og virkende faktorer $\mathrm{i}$ hændelsernes forløb. Bogen er at anbefale for den, der ønsker en kort og præcis orientering i problemkomplekset omkring de fantasifulde planer om et samlet Norden, den svensk-norske konges private skandinaviske politik og den for længe usikre svenske holdning, som vakte så farlige illusioner 
hos danske politikere, den hårde modspiller Bismarck over for den nok mest omstridte personlighed, D. G. Monrad, der var stor i dyder og fejl, Londonkonferencen, hvor det resultat, som først opnåedes i 1920, máske kunne have været nået ved smidigere forhandling, og Christian 9.s mange forgæves forsøg på at redde personalunionen. Alt dette gør de „otte foredrag“ til en betydningsfuld bog.

I "1864 - et hundredairsminde" har redaktorerne M. Friis Møller og Ernst Mentze samlet en lang række bidrag, hvori der redegeres for udviklingen op mod krigsudbruddet, for selve krigen på de forskellige fronter til lands og til vands, for hjælpen fra de norske og svenske frivillige og for litteraturen, også den skønlitterære, om 1864. Bogen afsluttes med en almen vurdering af udviklingen $\mathrm{i}$ årene derefter og tager stilling til, hvad artiklens forfatter kalder myten om 1864. Den produktive skribent, redaktør P. Stavnstrup, giver en levende beskrivelse af det dansk-tyske monarkis op'øsning, mens militærhistorikerne major C. F. Hagen, kommandor H. H. Wesche og museumsinspektør ved Tøjhusmuseet Egon Eriksen skildrer de militære forberedelser - eller mangel på forberedelser pá baggrund af den iøjnefaldende forpligtelse i den politiske situation - og krigens hele forløb, idet de i det væsentlige bygger på allerede offentliggjort materiale. Kaptajn J. G. W. Norrie fortæller om de frivillige, som blev landets eneste hjælp udefra, da „broderen var i nød“. Forfatteren Cai M. Woel giver en fyldig oversigt over de hidtil udkomne officielle værker om krigen og over de mange erindringsbøger, dagbogsoptegnelser og breve, som i løbet af et hundredår er fravristet skuffernes gemmer. Kun de færreste af disse, hvad udstyr og oplagstal angår, uanselige værker har fundet vej til Det kgl. Bibliotek eller til Dansk bogfortegnelse ved deres udgivelse. Arkivar Kristian Hvidt giver afsluttende en vurdering af nederlagets rent faktiske konsekvenser, geografiske som økonomiske, og af det bitre opgør i nederlagets skygge, hvor årsagerne til Danmarks ulykke så intenst diskuleredes. Det lykkedes i forbavsende grad de nationalliberale politikere at kaste skylden på hæren og flåden, i sâ høj grad, at Frede Boisen, der havde gjort krigen med, må beskrive sin hjemkomst til København på følgende måde: „København var regimentets garnisonsby; det var blevet oprevet på Dybbøl, hvorledes 
ville resterne nu blive modtaget $\mathrm{i}$ hjemmet? Derom havde samtalerne drejet sig under marchen; og da vi rykkede ud fra de sidste kvarterer mellem København og Roskilde, var det naturligt, at kompagnierne pudsede sig op så godt som muligt. Mon der flagedes i byen, eller er der bygget æresport? Vi skulle da vel marchere gennem byen? På Frederiksberg Bakke gjordes der holdt for at børste støv af støvler og klæder. Vi mente, at vi kunne vise en flot parademarch! Så begyndte indtoget ad Vesterbrogade - intet flag var at se - da vi kom til Frihedsstotten - ingen æresport - ingen velkomsthilsen. Da kommanderede chefen: Venstre sving - og vi drog uden om byen, idet vi skjult af voldtræerne nåede hen til Solvgades Kaserne, hvor vi trådte af uden et afskedsord. Stemningen var for bitter!"

Imidlertid er den udenrigs- og forsvarspolitiske opfattelse, som fandt udtryk i hærloven af 1867 , gennem hvilken der skulle skabes en kraftig feltstyrke, der kunne yde virksom hjælp til en stormagt i krigstilfælde, „et fuldgyldigt vidnesbyrd om, hvor hurtigt man overvandt nederlagets psykose, der var en naturlig følge af Dannevirke og Dybbøl.“ Vendingen kom ikke 1864, men 1870 efter Frankrigs fald. Det var da også først efter 1870, at slagordet „hvad udad tabes, det skal indad vindes“, blev formet. $1864 \mathrm{blev}$ ikke som tidligere fremført den direkte årsag til efterkrigstidens økonomiske og kulturelle opsving. De folkelige rørelser var begyndt før 1864 og ville uden et 1864 næppe have taget et væsentligt andet forløb, end de gjorde. Skellet sættes af historikere i dag ved $1870 \mathrm{i}$ modsætning til årtierne efter krigen, da „myten om 1864 “, hvor alt hørte op og noget nyt begyndte, spillede en væsentlig rolle. Imidlertid, fremhæver Kristian Hvidt, gør man ikke klogt $i$ at undervurdere de psykologiske virkninger "det indtryk, der som en slags bidrag til en livsholdning indprentede sig $i$ alle dalevende danske uanset partifarve eller social rang“. For ofte er de direkte konsekvenser blandet sammen med de mere umålelige, følelsesbetonede eftervirkninger. Vanskeligheden ved at måle denne faktor hænger sammen med, at "nye sociale og politiske idéer og bevægelser løber på tværs og skjuler 1864-motivet".

De indgående og brede skildringer af hændelsesforløbene støttes af en overordentlig mængde, fint udførte, illustrationer og af gode, store, klare oversigtskort og mindre kortskitser over val- 
pladser og befæstningsanlæg. I afsnit af vurderende art gøres undervejs status, og væsentlige årsager udkrystalliseres.

En grundig studie vedrørende våben og uniformer finder man i "Tøjhusmuseets bog om 1864". Deri skriver museumsinspektør, dr. phil. Arne Hoff om håndskydevåben, museumsinspektør Finn Askgaard om sidevåben og museumsinspektør Egon Eriksen om artilleriet, mens konservator Preben Kannik tager sig af uniformer og udrustning. Værket er mindre i omfang end museets bog om krigen 1848-50, idet det alene koncentrerer sig om behandlingen af våben og uniformer uden at medtage krigens almindelige historie. Dr. Hoff når, efter at have gennemgået de danske og de prøjsiske og østrigske troppers bevæbning - der var både i bevæbningsmæssig og taktisk henseende stor forskel på de to hære fra det tyske forbund - til en vurdering på baggrund af udviklingen på håndskydevåbnenes område. Heri fastslås, at „de to parter $i$ henseende til rækkevidde stod nogenlunde lige“. Hvad angår træfsikkerheden konkluderes, at "der var i det hele ringere feltmæssig træffesandsynlighed for vore våben, især taprifler, over for prøjsernes bagladerifler. Hertil kom så yderligere, at vore soldater sikkert havde ringere skydefærdighed end fjendens, dels fordi en væsentlig del af vore folk var uøvede rekrutter eller gammelt, genindkaldt mandskab over for fjendens unge, veltrænede tropper, dels fordi man i Danmark ofrede et mindre antal skud pr. skytte $i$ skydeuddannelsen end tilfældet var $i$ alt fald $i$ den prøjsiske hær". Hvad angår ammunitionsspørgsmålet skulle forladepatronerne - altså alle de danske og østrigske - bides af, hvorefter krudtet skulle hældes ned i pibens munding, medens den prøjsiske tændnålspatron i hel tilstand kunne indføres $\mathrm{i}$ kammeret, hvilket dels gav mere ensartede skud og endvidere muliggjorde en langt kraftigere ildvirkning. Det danske geværs ringe træffesandsynlighed virkede særligt uheldigt, da prøjserne var i stand til at betjene deres bagladevåben $i$ helt liggende stilling og derved frembød et meget ringe mål sammenlignet med forladeskytten, der måtte stå op under ladningen. Underkorporal H. P. Henriksen skriver da også, ,når prøjserne således i masse lavede hurtigskydning, var den aldeles forbavsende, hvilket kom af, at fængnålsgeværerne så hurtigt og let kunne lades“, ligesom han andetsteds i sine erindringer gør sig tanker om, hvor mange skud 
en mand får lejlighed til at gøre med forladebøssen, før fjenden braser ind på os. Det danske geværs underlegenhed var især udtalt under angreb. Det viser f. eks. affæren ved Lundby 3 . juli 1864. Det danske stormløb havde på få minutter kostet 1 officer og 31 underofficerer og menige i faldne, 2 og 42 i sårede af en styrke på ialt 4 officerer og 214 underofficerer og menige. Adskillige var ramt af mellem 3 og 8 skud. Prøjsernes tab var 3 sårede. Derimod mener dr. Hoff, at det danske gevær endnu var brugeligt, hvor der udkæmpedes forsvarskampe i feltbefæstninger. At de militære autoriteter i Danmark ligesom for øvrigt $i$ næsten alle europæiske lande havde forkastet bagladevåbnene kom til at koste dyre lærepenge. Vort infanteris dårligere bevæbning over for prøjsernes var dog ikke det ene afgørende for krigens udfald, men „kombinationen af en lang rad omstændigheder, både af uddannelsesmæssig, førelsesmæssig og materiel art“. For blankvåbnenes vedkommende understreger Finn Askgaard, at de i det hele taget ikke længere spillede nogen afgørende krigsmæssig rolle for de forskellige våbenarter, kavaleriet undtaget. Museumsinspektor Egon Eriksen beskriver sammenlignende de danske og tyske styrkers land- og søartilleri. Begge parter rådede over riflet skyts, men den danske hær havde kun riflede kanoner af mindre kaliber, udelukkende forladere, og havde derfor næsten ingen mulighed for at nedkæmpe de prøjsiske flankebatterier på Broagerland, der var anlagt „for at kunne beskyde de danske skanser med en flankerende ild bagfra og på langs ind i dem“. „Virkningen af det prøjsiske riflede bagladeskyts på Dybbølskanserne var et resultat af detle våbens rækkevidde og træfsikkerhed og af den benyttede ammunitions indtrængningsevne og sprængkraft over for det danske materiels utilstrækkelighed". Kun den berømte Skanse 2 kunne med sine 2 riflede 12-punds kanoner genere de prøjsiske batterier væsentligt. Om 64-krigens dystre uniformer skriver konservator Preben Kannik, at modsætningen til treårskrigens festlige uniformspræg var slående. Den danske hærs foreskrevne mundering og beklædning har i hvert fald været på højde med modstandernes, i nogle henseender lidt bedre. Således er de prøjsiske soldaters misundelse over de fortrinlige danske feltflasker ejendommelig at bemærke. Blot manglede tilstrækkelige mængder af den udmærkede mundering. De varmende be- 
klædningsgenstande, som blev indsamlet af private komiteer, bidrog til at give soldaternes ydre et uensartet præg. Ludvig Koch bemærker i et brev: „Nu skal alle de herværende trænkuske bort, så jeg bliver nok snart ene tilbage. Du skulle se dem nu i mundering. En del af dem er vel kønne karle, hvem uniformen klæder, men en del er også de latterligste figurer, og tilmed er munderingen for manges vedkommende meget ufuldstændig. Der er folk med uniform og træsko, andre har blot fået en gammel infanterikappe, som de bærer over deres egne klæder, og så ser man oven for det hele en lådden hue eller rund hat; en har endog en gammel sort hat. Det kan ikke nægtes, det er et Pjaltenbergs regiment.“ Tøjhusmuseets bog er en af de gode specialfremstillinger, hvori der fremlægges et stort eksakt materiale.

I Jernbanehistorisk Selskabs skrifter giver E. L. Parbøl en skildring af "Jernbanerne i krigen 1864", hvor bl. a. jernbanemuseets arkivstof er benyttet foruden især $\mathrm{H}$. H. A. Rambuschs jernbaneerindringer. Bogen, der er forsynet med nyttige personhenvisninger, beretter om jernbanenettets bygning op mod 1864, ikke mindst banerne i Sydslesvig, og Parbøl fremhæver, at „man skulle have forventet, at de sydslesvigske baners tilstedeværelse ville have gjort sig gældende under krigsførelsen i 1863-64. Men dette var mærkeligt nok ikke tilfældet $i$ så høj grad, som man kunne have formodet". Vel havde overkommandoen afsluttet kontrakt med det sydslesvigske jernbaneselskab vedrørende banens deltagelse $i$ hærens transporter, men nyt og uprøvet som det var, havde man ikke tænkt på at etablere et nærmere samarbejde mellem hæren og jernbanens administration, f. eks. ved at indsætte transportofficerer på vigtige punkter. Jernbanerne kom ikke til at spille nogen væsentlig rolle ved tilbagetrækningen fra Dannevirke, hverken som troppe- eller godstransport. Mistolkede tidspunkter for indladning af fæstningsskyts $i$ det nedsendte jernbanemateriel på grund af instruksernes uklarhed resulterede $i$, at kun nogle artillerister, om hvis befordring der ikke havde været tale, kom til at benytte de ventende tog. Til skildring af jernbanernes betydning for krigen i Nørrejylland bruger forfatteren især Rambuschs erindringsbog.

Johan Chr. Holm: „Danmarks krigsmedailler" bør næunes blandt den mere specialbetonede litteratur. Der gives heri en over- 
sigt med illustrationer og beskrivelser over erindringstegn, herunder også af krigsmedailler fra treårskrigen, 1864 og for deltagelsen $i$ begge krige.

Et planlagt, større arbejde om krigens forløb fra forsvarsministeriets krigshistoriske afdeling, hvor nye enkeltheder, som er fremkommet efter den sidste menneskealders grundige militærhistoriske forskning, skal indarbejdes, er endnu ikke kommet. Det samme er tilfældet med det illustrerede værk, der som et dansk-tysk fællesforetagende skulle være det blivende resultat af den i marts 1964 arrangerede dansk-tyske udstilling på Det kgl. Bibliotek af samtlige billeder fra krigen. ${ }^{4}$

En væsentlig del af den ny 1864-litteratur har koncentreret sig om at gøre krigsårets billedstof let tilgængeligt. Der er udgivet flere samlinger af især samtidige billeder. Gennem det direkte illustrative stof træder begivenheder og personer frem på en håndgribelig måde, som nok tiltaler vor tids mennesker. Det er især træsnit og litografier, baseret på skitser af de malere og tegnere, der opholdt sig ved fronterne, som dominerer, men den fotografiske reportage, som for første gang blev taget $i$ brug på vore himmelstrøg under så ekstraordinære omstændigheder, giver nøgternt autentiske indtryk fra krigsskuepladsen. Sammenlignet med vor tids fantastiske krigsbilleder var det kun beskedent, hvad fotograferne af 1864 formåede. Teknisk set var det kun muligt at affotografere opstillede grupper af soldater eller scener fra slagmarken før eller efter kampene. De egentlige kamphandlinger måtte endnu skildres gennem tegninger, der senere blev mangfoldiggjort eller tjente som forarbejder til malerier, altsammen med tab af det autentiske til følge. Fra dansk side kendes fotografier af den københavnske fotograf Georg Hansen, som sendte den 36-årige Vilhelm Schrøder til Sundeved for at optage de dengang så populære stereoskopbilleder. Fra tysk side har vi en række optagelser, udført til forherligelse af sejren på befaling af prins Friedrich Carl, af fotograf Chr. F. Brandt fra Flensborg, billeder, som skaffede ham titel af hoffotograf. Desuden den hamborgske fotograf C. Junod, hvis optagelser fra skanserne dog ikke kommer på højde med Brandts. Herudover findes en mængde „photografi-portrætter" taget i Flensborg, Sønderborg, Vejle og Fredericia af officerer og menige, som en hilsen til dem derhjemme. 


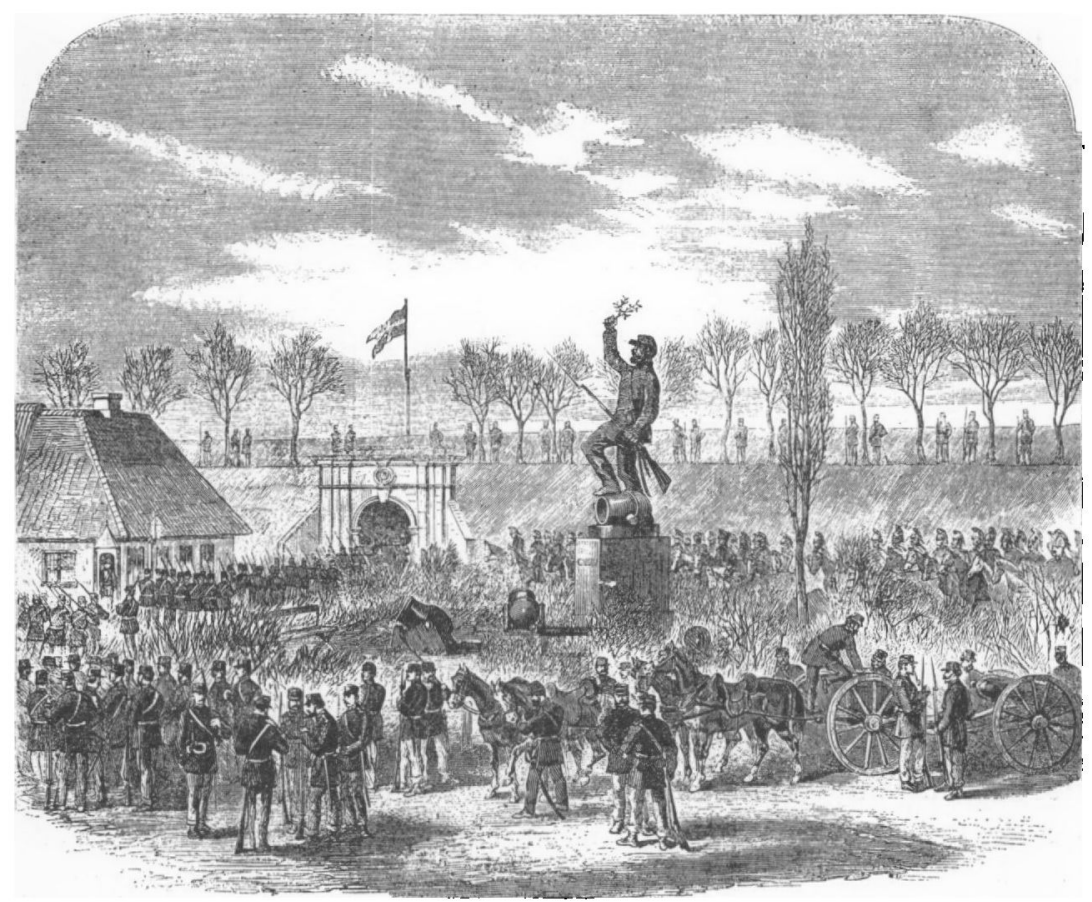

Scene bag Fredericias volde. Soldaterne rykker ud af byen for at komme deres nordligere betrangte landsmand til hjalp - under trafningerne ved Vejle 8. marts. Efter traesnit i Ill. London News 2. apr. 1864, skabt på grdl. af en tegning, som en dansk ingenior Nielsen $i$ Fredericia har sendt bladet. (Efter T. Vogel-Jorgensen: „Krigen 1864“).

Træsnittene og litografierne er som historisk kildemateriale betragtet af stærkt varierende værdi. Frederiksborgstilens billeder fra 1864, som museet viste frem på en nydelig udstilling, er gennemgående svagere repræsenteret $i$ fremstillingerne, og deres værdi som historisk billede er da også for en hel dels vedkommende ringe. De fortæller ofte mere smagshistorie end Danmarkshistorie.

Det kan derfor kun hilses med tilfredshed, at jubilæet har givet flere forlag anledning til at reproducere et stort udvalg af billedmaterialet, som herved er blevet kendt af et større publikum. Med titlen "Krigen $1864 i$ samtidens billeder" har redaktør $T$. Vogel-Jørgensen udsendt et billedudvalg med korte, præcise tekster, der klart angiver, hvorfra billederne er hentet. Materialet stammer for en stor del fra Illustreret Tidende i København, Illustrated London News og det tyske Illustrierte Zeitung. 
Forfatteren Palle Lauring har udsendt "en billedbog med tekst", som han selv kalder den. Han vil i værket „1848-1864" skildre de to slesvigske krige gennem samtidige billeder af forskellig art. Palle Lauring, der længst har leveret bevis på, at han kan popularisere et historisk stof, har gennem udvælgelsen af det fyldige billedstof, der er bogens stærke side, givet ikke mindst undervisere i historie et gavnligt supplement. Det er netop derfor at beklage, at han ikke har of ret mere plads til at fortælle on selve billedernes tilblivelse og tidspunktet for offentliggorelsen, end tilfældet er, ikke mindst fordi teksten, omend skrevet med overbevisning, ikke altid virker overbevisende.

Redaktør Lars Lindeberg giver i værket "De så det ske" ordet til soldater og civile, som var med, og til samtidige journalister og forfattere, mens malere, tegnere og fotografer illustrerer begivenhederne. I kronologisk orden og med sans for opsætningen er der af de store og væsentlige begivenheder og af de små, men for den enkelte ingenlunde uvæsentlige hændelser, skabt den populære og farverige fremstilling. Vi er hele tiden der, hvor det sker, og oplever det skete med de implicerede. Et væld af detailler krydrer oversigten, og i glimt gives der en fornemmelse af krigen og krigens hverdag. Der fortælles f. eks. om Madam Mangor, som i sin "Kogebog for soldaten i felten“ skriver, at „udgiverinden af de efterfølgende blade har troet, ved de deri givne anvisninger til tilberedning af de soldaterne udleverede fødemidler, at yde en, omend ringe, skærv til at lette vore tapre soldater de byrder og besværligheder, som felttoget medfører. Måtte dette blive tilfældet, da er hendes onske opnået". Der berettes om soldaternes sange, ${ }^{5}$ om menig Jacob Jacobsen af 21 . regiment, der fik sin pibe, den for alle soldaterfremstillinger uundværlige, skudt igennem, men selv slap uskadt, om menig Schebels feltsalmebog, om marketendere, der kun tænkte på at tjene penge, om feltlazaretter og amputationer, om krumslutning og andre straffe og meget mere. Cand. mag. Johs. Fabricius har forsynet bogen med en kort indledning.

Museumsinspektor Erik Kjersgaard og fotograf Wermund Bendtsen har udsendt en billed-og tekstbog betitlet „Fra Dannevirke til Dybbøl". Vilh. la Cour har skrevet indledningen. På baggrund af tilbagetoget i 1864 skildres de mange fra Danmarkshi- 
storien kendte lokaliteter med fredelig eller krigerisk klang fra kong Gudfreds til vore dage. Med de dødtrætte retirerende soldater genopleves ikke blot hin nat, men i glimt en tusindårig historie. Det smukke billedværk yder en hjælp for de mange, der vil opleve denne "via dolorosa" og søge til åstederne for virkelige begivenheder i vort folks historie.

Selv om det kun er de sidste billeder, som har direkte relation lil 1864, er der dog god grund til at nævne det prægtige billedvork med ledsagende tekst, som Historisk Samfund for Sonderjylland har udsendt. Deri fortælles om landsdelens historie, nationalt og kulturelt, fra den tidlige middelalder til 1864. Billedredaktionen er lagt i hænderne pâ museumsdirektør Jorgen Paulsen, Frederiksborg, og tekstsiderne er skrevet af bibliotekar Poul Kürstein, Slesvig. Der er her skabt en bog, velegnet til i det folkelige arbejde at sprede oplysning om den landsdel, der strækker sig fra Ejderen til Kongeảen. Som det rammende formuleres $i$ forordet: „En Sønderjyllandshistorie, fortalt på en ny måde i vor lids eget sprog". Man kan kun habe, at fortsættelsen, som det er hensigten at udsende i 1970 , må blive muliggjort.

Den allerede lange række erindringsbøger fra 1864 af forskellig slags, som er blevet of fentliggjort i det forløbne sekel, ${ }^{6}$ blev i mindeåret forøget med flere værdifulde udgivelser. Brevsamlinger, dagbøger og erindringer fra den gang synes slet ikke at ville tage en ende. Vel fortæller stof af den art mest om den, der beretter, men det giver på en direkte måde læseren af $\mathbf{i}$ dag mulighed for at stifte nært bekendtskab med de stemninger og standpunkter, som var danskerens i 1864 .

På grundlag af breve fra familiens arkiv offentliggor dr. phil. lilhelm la Cour faderens - den senere leder af landbrugsskolen i Lyngby J. C. la Cours - breve til hjenmet og især til hans daværende forlovede og senere hustru, datter af historikeren og politikeren Frederik Barfod. La Cour gjorde hele krigen med som reserveofficer. "Med Far i Felten" er ikke blot en brevsamling, men har gennem den forbindende og refererende ramme, sønnen har givet den, snarere fảet karakteren af en samlet fremstilling. Med den nulevende historikers kendskab til sammenhænge, som ikke kunne være faderen bekendt, korrigerer sønnen forstående soldatens undertiden forhastede domme og vurderinger. I tempe- 
ramentet ser man dog tydeligt ligheden. Ligesom fuderen den 18. april ikke „forstod“ ordren om at gå tilbage, „der mâtte være dikteret af konfuse overordnede, der tabte næse og mund“, viste sønnen senere samme mangel på „forståelse“. Det er ikke først og fremmest beskrivelsen af soldaterlivets forskellige sider under kampforhold eller vagttjeneste eller efter aflosningen, som gør denne bog til noget særligt, men især de stærke indtryk af følelser og skiftende stemninger hos brevskriveren og hans omgivelser, som træder så stærkt frem. Efter Dannevirkes rømning skriver han i dybeste fortvivlelse og mismod: „Nej, det var ikke til udfald fra Mysunde, som vi havde tænkt os ... det var til den sørgeligste, den tungeste gerning, vi blev kaldede... som tyve om natten måtte vi stjæle os bort... jeg kunne fristes til at knække min sabel og kaste den bort, når jeg berøves retten til at bruge den. Hils hver den, der - bryder sig om en hilsen." Og den 19. april: „så er det da sket - så har vi da måttet tømme også den skål, og har vi været for hovmodige, for selvtillidsfulde, for pukkende på egen kraft, så er vi i sandhed ydmygede - kuede er vi endnu ej, og med Guds hjælp skal aldrig det danske folk blive det. Alt som trængslerne øges, skal folkets spændkraft vokse, og lutret og styrket skal de gode elementer i folket, dets vakte nationalfølelse og dets kristelige liv, gå ud i kampen for i fredens dage at føre os til det mål, hvortil kampen med krigens våben dog aldrig ville kunne fore os - til et virkeligt dansk rige til Ejderen, ej blot dansk af navn, men dansk i hver sin del“".

"Med Far i Felten“ tegner et levende billede af de følelser, som krigen fremkaldte blandt datidens unge generation af grundtvigsk prægning.

Fra den senere bekendte kirkehistoriker Ludvig Koch foreligger en brevsamling fra december 1863 til august 1864. Denne samling er allerede tilrettelagt 1912 af ham selv samtidig med, at han skrev sine erindringer, som på flere punkter supplerer brevstoffet. Brevdagbogen er udgivet af hans oldebarn Hans $P$. Koch, som fandt den blandt faderens, professor Hal Kochs efterladte papirer under titlen „Mit soldaterliv". Udgivelsen er for så vidt bemærkelsesværdig, som Ludvig Koch, der var ung teologisk kandidat, aldrig nåede til fronten. Han kan i brevenet til sin kæreste og til hjemmet hverken berette om begivenhederne ved Danne- 
Kobenhavn den 17. april 1864: Det kgl. Teater spiller - af alle stykker "Soldaterlojer". (Fra L. Lindeberg: „De så det ske").

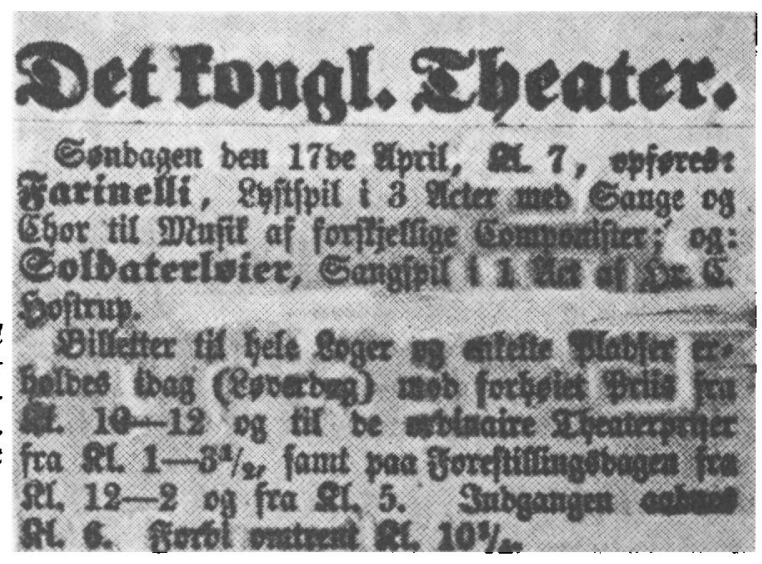

virke, på Dybbøl eller Als, men om det ensformige liv som trainkusk i Odense og Fredericia og om sin tid som rekrut i Odense, hvortil han kom efter egen ansagning, og sluttelig om vagttjeneste langs den fynske kyst og skiftende kantonnementer på Vestfyn. "Næsten hele tiden har jeg haft det bedre end de fleste andre". Stemningerne skifter mollem lyst til at "massakrere en halv snes tusind mand" og lede ved krigen, men soldatertilværelsen bærer han „for det kan kun nytte lidt, at vi taler og synger om vor kærlighed til fædrelandet, når vi ikke vil vise det $i$ gerninger". Han kan skrive, så man får en ikke ringe fornemmelse af både personer og tiden. Afstanden mellem akademikeren og det jævne folk af „,andre klasser" kommer flere gange frem, og den kræsne dannede forundres ofte, men tilstår også, at „uniformen nok skal pille alle aristokratiske nykker ud af ham". Gennem de skiftende kvarterværter lærer han ikke så lidt om „,den gemene mand“, „det er gode og flinke mennesker, men det går her, som jeg synes, det altid går med mindre dannede folk, de ældre er behageligere end de unge og konen end manden“. "Men“, skriver han, „tro mig, jeg skal nok lære noget $i$ dette liv, især at omgås venligt med alle folk. Det har jeg ikke før ret kunnet. Men i det stykke er jeg i en god lære, og jeg skal siden ikke glemme, hvad jeg har lært".

Det Berlingske Bogtrykkeri har som årspublikation udsendt den sjællandske gårdejer $H$. $P$. Henriksens erindringer og breve under titlen "Feltliv". Her fornemmes et ganske andet tempera- 
ment. Med sjællandsk lune og med megen sans for de små ting fortæller han, ofte med et glimt $\mathbf{i}$ øjet, om krigens strabadser og små glæder. Han gjorde hele felttoget med som underkorporal. Vi møder sjældent det oprør mod politikere og militærledelse, som den engagerede la Cour ikke kan tilbageholde. Derimod skinner oftere den uheroiske jævne danske mands besindighed igennem, og som felttoget skrider frem, og tingene går deres skæve gang, en stadig voksende lede ved krigen og dens råhed. Under kampene ved Mysunde beretter Henriksen om et ordskifte, han havde med cand. teol. Bredsdorff under indtryk af synet af de mange, der faldt rundt omkring: „Jeg spurgte ham i egenskab af teolog, hvem der måtte anses for at være årsag til en så forfærdelig redelighed og sådant menneskeslagteri". Han svarede: „Det er menneskenes egen ondskab“. .Ja, men dog vel ikke soldaternes“, indvendte jeg. Henriksen brugte sine øjne, og adskillige steder fortæller han, der virkelig kan fortælle, om sprog og sæd og skik. Fra Als beretter han: „Als er ellers et udmærket smukt land, med store, smukke gårde og vist nok fortrinlig agerjord. Man kan næsten blive vildfarende $\mathrm{i}$ bare værelser på et bondested, møbler og bohave haves $\mathrm{i}$ rigelig mængde. Gårdene består ikke som de $\mathrm{i}$ Sydslesvig af 1 bygning, men ligesom på Sjælland af flere, køkken, lo og lade gå ud i eet i Sydslesvig, men her er anderledes orden. Landet (Sundeved) på den anden side sundet er lige så smukt som Als; de er nogle af de dejligste landskaber, jeg har set. Beboerne er begge steder dansktalende, dog med et eget dialekt. I Flensborg, hvor vi på retraiten opholdt os nogle timers tid, taler de dels tysk og dels dansk; de fleste kunne begge dele. I nordenden af byen især var de næsten alle overordentlig flinke mod os; de gav os spise og drikke gratis, uddelte øl, brændevin, kaffe, hvedebrød til de utallige militære, der trak igennem byen, og vi kunne nok trænge til det, eftersom vi havde marcheret i 14 timer $i$ frost og våget i flere nætter". Denne nogterne egnsbeskrivelse er altså afsendt $i$ brev til hjemmet få dage efter marchen fra Dannevirke! Meget til overs for slesvigerne i kompagniet har han ikke: „Disse rakkere stikker af, over til tyskerne, så såre de kan se deres snit, både på forpost og under fægtning (dette gælder naturligvis langt fra dem alle) “. Og den danske overkommando går så vidt $\mathrm{i}$ defensiven, at "regimenterne sluttelig begyndte at gøre 
„Stricke“ og rent ud nægtede at ligge derovre som granatføde på bankerne længere, når de ikke måtte få lov at rydde op i de fjendtlige rottereder derude."

Pastor Erik Spur har udsendt et tidsbillede fra 1864, der giver „et indtryk af tilstande og stemninger $i$ et dansk $h$ jem, hvor familiens ældste søn som løjtnant af 20 . regiment var med ved Dannevirke og under tilbagetoget deltog i den blodige kamp ved Sankelmark". Efter ophold i Fredericia var Alfred Neergaard, som løjtnanten hed, med i kampene i Dybbøl skanser, hvor han blev såret. To måneder senere døde han på det lazaret, som var indrettet i Borgerforeningen i Flensborg. Han ligger begravet på den gamle kirkegård. Neergaard var søn af en apoteker fra Kerteminde. Hans mor, Laura, var en søster til Chr. Hostrup. Efter sin forste mands død havde hun giftet sig med pastor Henrik Spur, Hobro, der var B. S. Ingemanns søstersøn. Deres ældste søn, Christian, var far til her omtalte bogs forfatter. De fleste af brevene er fra Henrik og Laura Spur til sønnen Christian, der går på Frederiksborg lærde skole og bor hos morbroderen Chr. Hostrup. Vi følger herigennem løjtnant Neergaard og hans sørgelige skæbne, ligesom vi hører om, hvorledes den civile befolkning tog de mørke dage, som krig og besættelse førte med sig. Henrik Spur, der begravede de mange ofre fra kampen ved Lundby, skriver derom: „Tre af vore sårede ligger endnu på lazarettet, om overlægen kan holde liv i dem. Da den sidste begravelse fandt sted, var der stort vrøvl med prøjserne. Jeg havde kaldt dem „fjender“. Kommandanten sendte sin klatmajor til etatsråden at forhøre, om der ikke var noget fornærmeligt i præstens tale, men han afviste det. Nu ved du omtrent, hvordan vi har det. Vejret er yndigt og humoret så godt, som det kan være i disse tider." Og lidt senere: „Da tysk er afskaffet $i$ vor skole, spekulerer Astrid på at sætte italiensk i stedet for."

Forening for Boghåndværk har udgivet „Dagbogsblade fra 1864", optegnelser af menig Frederik Hansen, Nybøl, ved Claus Nielsen og J. Slettebo. Frederik Hansen, der var kådner og håndværker, har $i$ en lille lommebog indført kortfattede notitser fra sin tid som værnepligtig i Flensborg i 1853-54 og senere, da han på ny blev indkaldt i 1864, fortsatte han sin militærdagbog, nu bredere fortællende. Skønt han var blevet gift i 1860, optager 
familie og hjem ikke plads i dagbogen. Han lå først i Fredericia, hvorfra han fortæller: „Der maatte vi løbbe i Gaderne for at faa Qvarteer, dog saaledes at vi kunde komme under Tag, der maatte vi pleie os selv, og lidt Straa fik vi kun til at ligge i.“ Han deltager i udfald. "Det lykkedes os ikke at tage Tobakshuuset. Vi maatte tilbage igjen og tage Dækning bag nogle Møibunker. Endnu da vi havde været $i$ Ilden den heele Dag indtil sildig Aften, maatte vi endnu blive, og da den største Deel havde deres Patroner Bordtskudt, blev der midt om Natten frisk Amunation udleveret til os, paa Marken hvor vi laae. Endeel af os havde Tap-Riffler og endeel Menie-Riffler, men alle fik vi eens Amunation, paa Grund af, at de havde ingen anden end til Minie-Riffler, men vi fik ikke noget meere brugt der." Under stormen på Dybbøl blev han taget til fange. „Der var flere Fanger, vi blev fort under Bevogtning til Graasten. Da jeg kom igjennem Nybøl, fik jeg lov til, et øieblik at løbe hjem og da vi alle var $i$ den stærke Meening, at vi alle fra Schlesvig, naar vi var kommen til Flensburg, saa blev Permiteret, $i$ den gode Mening reiste jeg fra mit Familie igjen til Graasten." Men det gik anderledes. Han blev ført til Schweidnitz i Schlesien i krigsfangenskab. Forst hen i august kan han slutte sin krigsdagbog på følgende lakoniske måde: „Jeg kom hjem den 20de om Morgenen Klokken 7.“ Dele af teksten er allerede tidligere udgivet af forfatteren Karl Larsen, men, som udgiverne påpeger, efter en senere renskrift. Den her publicerede udgave følger fuldstændig originalen, både med hensyn til knortet stavemåde og også med hensyn til synspunkter, i modsætning til den pyntede renskrift, som Karl Larsen har benyttet, der viser, at Frederik Hansen i den mellemliggende tid er blevet mere nationalt bevidst.

De bekendte og skattede „Krigsminder fra Dannevirke og Dybbøl" af gårdejer Chr. Christensen, Dons, der allerede fremkom i 1884 i Højskolebladet og senere i bogform, er blevet genudgivet af datteren, cand. teol. et mag. Marie Christensen. Disse erindringer, der må regnes blandt de bedste, vi har, beretter fængslende om Dannevirke, tilbagetoget og Dybbøl, hvor forfatteren som fæstningsartillerist gjorde tjeneste under Castenskiold og Anker i den berømte skanse 2 .

Den beundrede kommandør J. Anker, der var en af de forholds- 


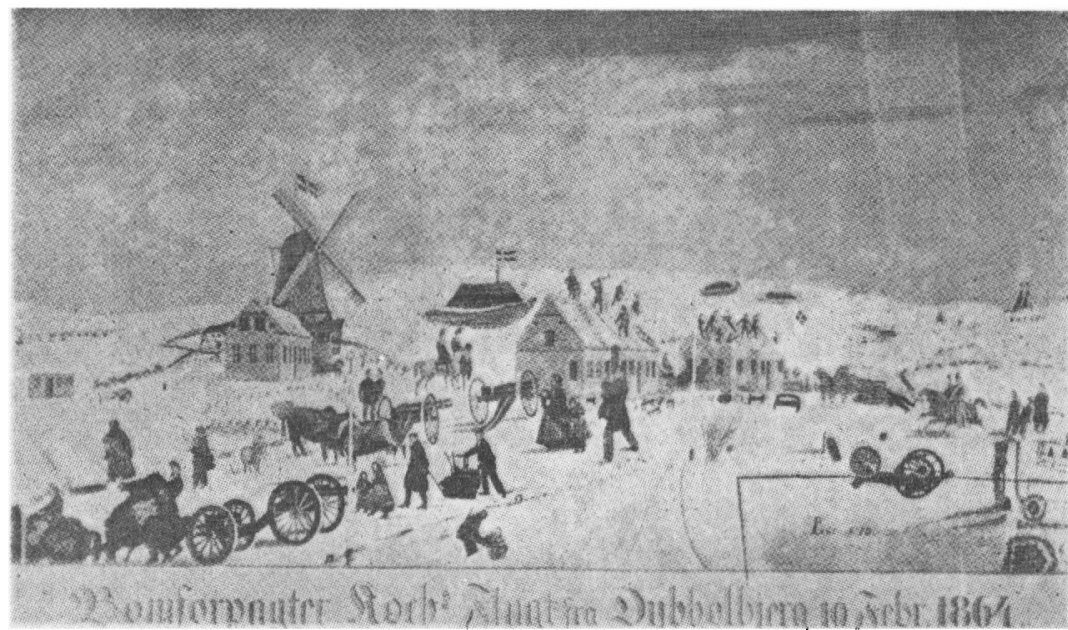

Samtidig litografi af „Bomforpagter Kochs Flugt fra Dybbolbjerg den 10. Februar 1864". Teksten pa bagsiden af det naivt udforte billede oplyser, at det er bomforpagteren med kone og 8 born, der ses midt i billedet. Nogle mand er i fard med at nedbryde huset, overvaget af et par officerer til hest. Familiens bohave bliver kastet ud $i$ sneen. I groften blev Kochs 71 -årige moder fundet af en soldat. Episoden gav anledning til strerk kritik, idet Koch var blevet tvunget til at flytte 6 gange $i$ lobet af krigsairet, uden at modtage nogen erstatning. (Fra „1864 - et hundredarsminde").

vis få bornholmske frivillige, som meldte sig under fanerne, har fundet en hædersplads i den mosaik om „1864, Bornholm og Krigen om Sonderjylland", som Christian Stub-Jorgensen har samlet. Det er især beretninger om lokale bornholmske forhold og bornholmernes tilbageholdenhed, da det gjaldt at stille sig frivilligt til kampen for gamle Danmarks fremtidige beståen «. som belyses, ofte ud fra dagbladsstof.

Redaktør Benny Siewertsen har samlet en række krigskorrespondenters beretninger om kampene og feltlivet ved Sønderborg og Dybbøl under titlen "Krigen 1864":

I fortællende form har Aage Mogensen udgivet en skildring af begivenhederne, betitlet "Soldaten og den tabte Krig", på grundlag af tidligere trykt materiale. Titlen lover på sin vis mere, end bogen holder. Når, som forfatteren skriver, bogen er tænkt som vor sene tak til soldaten, der kæmpede i 64 , har behandlingen af den menige soldat som agte dansk menigmand $i$ uniform fået alt for lidt af pladsen i en tyk bog. 
Såvel i det 1864-særnummer, som Sonderjysk Mainedsskrift har udsendt, som i bogen "Als og Sundeved $i$ 1864", udgivet af Historisk Samfund for Als og Sundeved, gor redaktorerne med rette opmærksom på, at civilbefolkningens hverdag i 1864 slet ikke på samme måde som de politiske og militære forhold har fristet til mange fremstillinger. I begge skrifter har man søgt at bøde på dette forhold ved at udgive uddrag af dagbøger, breve og erindringer $i$ øvrigt $i$ kommenteret form. Der er herved bragt et værdifuldt materiale frem fra forskellige kredse i den befolkning, som blev berort af krigen både materielt og åndeligt, et stof, som for en dels vedkommende ikke før har været udnyttet og offentliggjort. For de mange blev indkvartering af soldater og udskrivning til krigskørsel hverdagsbegivenheder. Chr. Jensen Wyff skriver herom: „Den 18. februar ankom de første prøjsere hertil. Vi fik 1. komp. ca. 200 mand og 30 husarer, som kogte, stegte og spiste her i et par timer. (Noget havde (de), noget tog de, og noget måtte vi levere uden betaling). Derpå marcherede de til Kolding. Vi fik da på ny et komp. ca. 200 mand og $\mathbf{4 0}$ mand og ditto hesteartilleri, som ligeledes spiste og drak uden betaling, og tog bort kl. 5 eftermiddag til Kolding. Om aftenen kl. 10 fik vi artilleri 60 mand og ditto heste og 7 husarer, som blev natten over, vi leverede flæsk til dem for betaling, de var de bedste, vi har haft, men det er næsten den værste dag, jeg har levet under okkupationen, og min kone har hele tiden ligget syg af ansigtsrosen. Der er endnu mange her $\mathbf{i}$ byen, men vi har ingen. Hertil har Herren hjulpen og vil fremdeles.“ $\mathrm{Og}$ den 20 . marts 64: „... Ammunitionskolonnen afrejste først $i$ gâr og $i$ dag ankommer en lignende her til byen. Vi korer altid ægt med 1 vogn og undertiden med to, så at arbejdet bliver næsten til intet..." Skrivelsen fra inderste Jens Hansen af 28. februar 1867 til overpræsidenten for hertugdømmerne Slesvig og Holsten, skrevet på dansk, taler sit tydelige sprog om krigens ødelæggelser og befolkningens nød: „Da min kone og jeg den 13 . marts 1864 af det kongelige danske infanteri blev udkommanderede af vort hus, og dette i samme ajeblik stod i lys lue, fik vi intet andet bjerget end vore $2 \mathrm{k} ø e r$, medens al vor øvrige ejendom blev et rov for luerne. Vi beordredes til Sønderborg og kom ikke tilbage før den 27. maj, da vi fandt alt afbrændt og ødelagt. Det var uhyre svært for os at få vore bygnin- 
ger genrejste og det fornødne husgeråd anskaffet, og det meget mere, som vor angivelse af mobilier var for lav, ligesom også vort hus var for lavt takseret, hvilket alt ikke lod sig forandre, da vi i fire uger lå mellem de fjendtligt opererende tropper og ikke kunne forlade huset, før det lå i aske... “ I billedets form fortæller snedkermester Jørgen Jensen, Ullerup, 11. juni 1864 i et brev til den ældste søn, bosat i Dresden: ..., ,Nu spørger du vist, hvorledes har I haft det $\mathbf{i}$ denne krig, hvorledes ser Sundeved og omegnen ud, og hvorledes har prøjserne opført sig, for at besvare det sidste kort, så vil jeg tage en lignelse. Når en stor flok køer brækker over i en kløver- eller rugmark, så løber den om, bider toppen af, skider på og nedtramper resten, og så brøler de, når de har ødelagt alt og nu intet har at æde, dette er en kort, men sand skildring af prøjsernes færd, især hvad den første tid angår..." I gårdejer Mathias Hollensen, Broagerlands, omhyggeligt førte dagbog afspejler blandingen af krig og hverdag sig tydeligt. 17. februar „Tærskede rug og hvede. Der var nogle prøjsiske militære i Broager, de tog præsten med. Lidt frost." 14. april „Der hørtes geværskud om morgenen. Kanonade vedblev endnu. Stærk brand i Rønhave. Der sagdes, at der havde været et hårdt slag. Prøjserne tabte mange folk, om danskerne ved vi intet. Temmelig nattefrost, smukt vejr." Det er to særdeles oplysende samlinger, som her er skabt til veje, fyldt med krigens hverdag og gru.

Bengt Holbek og Anna Piø har med assistance af arkivar Hans Worsøe udgivet den vigtige samtidige dagbog af Martin Bahnsen med undertitlen, En rådmands beretning om Ảbenrås bescettelse 1864-66“. Til belysning af forholdene og borgernes holdning i det af fjenden besatte Åbenrå udkom tidligere Frederik Fischers dagbøger. Disse supplerer på mange punkter Bahnsens, der imidlertid må anses for mere pålidelige. Bogen er som kilde af stor værdi. At vi har bevaret disse førstehåndsindtryk fra to af de ledende dansksindede $\mathbf{i}$ byen er noget enestående, da private papirer ofte er tilintetgjort af frygt for de civile myndigheders efterforskning i tiden derefter. Martin Bahnsen var farvermester. Han havde i øvrigt lært hos sin svoger, farver M. A. Jørgensen i Gråsten, A. D. Jørgensens far. I mellemkrigsårene gjorde han en fremragende kommunal indsats. Af dagbøgerne lærer man hans danske sind at kende, og en dyb modvilje mod de „meerum- 
schlungne“, „denne væmmelige yngel af landsforræddere“, hans uimponerethed af de "todesmutige" prøjsere, der „før skanserne var faldet, var tavse, nedtrykte, ja forknytte i høj grad, men beskedne og lette at tilfredsstille, nu derimod er de blevet larmende, syngende, skrålende, brovtende og fordringsfulde $\mathbf{i}$ det uendelige." Hans politiske og nationale standpunkt kommer til orde 17. maj 1864: „Fra flere sider hører man, at der vil udgå et forslag i konferencen fra de neutrale magter om en deling af Slesvig, så at den rent dansktalende del lægges til Jylland, den tysktalende til Holsten, og i det blandede distrikt bestemmes det ved afstemning, til hvilken af siderne de vil gå ... Jeg for mit vedkommende ville naturligvis onske den af hjertens grund, thi derved var da for det første den danske del sikret, og lad så resten for pokker gå, hvorhen den vil, vi har ingen grund til at ønske for fremtiden at beholde flere af dem, end de, der godvilligt vil gå med os.“ Efter afståelsen udtrykker han sig den 24. december 1864 således: „Aldrig nogen sinde før er en så bedrøvelig juletid oprundet for os som denne. Erobret af vore ærkefjender, regeret af udskuddet af det usleste parti, der findes $i$ verden, "Schleswig-Holsteinerne“, ser vi danske slesvigere den mørkeste fremtid i møde, og dette sker i den sidste halvdel af det 19. århundrede, hvor Europa tror sig på civilisationens højdepunkt, at alverden ser roligt til, hvorledes et indtil det yderste demoraliseret røverfolk, som er os tyve gange overlegent $i$ tal, overfalder og sønderlemmer et af de ældste riger i Europa for at tilfredsstille sin trang til at blive en sømagt og i sin higen efter krigerisk hæder, som det her troede at kunne tilfredsstille for lettest køb. Dette foragteligste af alle folkeslag, som i sin demoraliserede tilstand ikke har evne til at fatte, at det ved sin væmmelige brovten og udbasunen af sine heltegerninger pådrager sig hele verdens hån og foragt, dette folk skal vi nu for fremtiden tilhøre og stå under! Hellere måtte man være blevet kineser eller hottentot!“

Om befolkningens nød og trængsler i den hårdt medtagne landsdel Sundeved har Th. Kaufmann samlet mundtlige og skriftlige overleveringer fra tyskernes invasion under titlen „I Fjendevold“. De skriftlige overleveringer støtter sig især på de af præsterne N. L. Feilberg, Ullerup, M. Mørk Hansen, Felsted, og Roth, Var- 


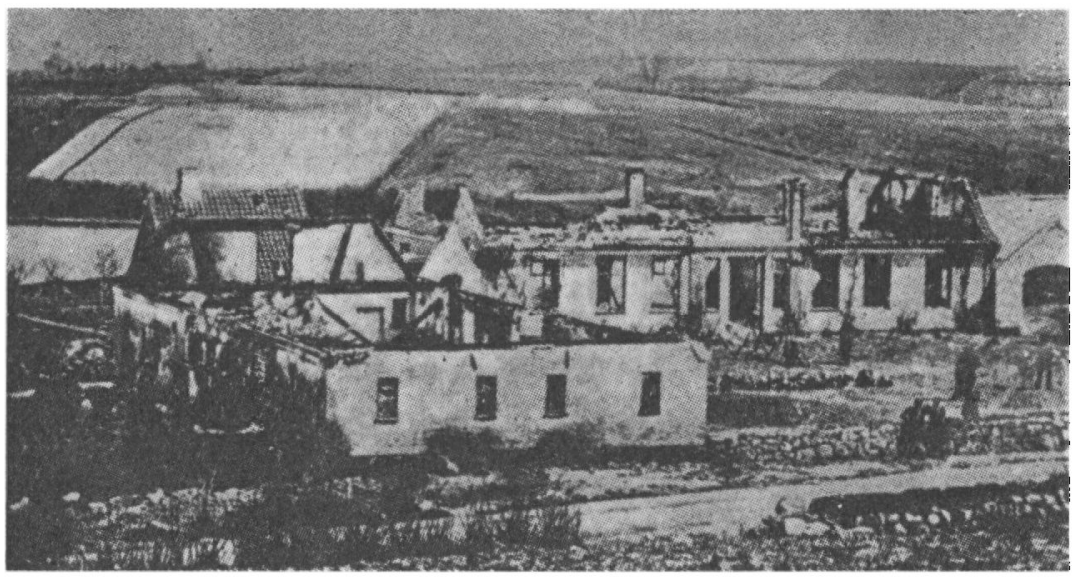

Udbrandt gård 1864. De gensidige beskydninger gik også stærkt ud over huse og gårde i terranet. (Fra L. Lindeberg: "De så det ske“).

næs, udgivne breve og dagbøger. Bogen er illustreret med billeder fra soldatergrave.

I en meget detailleret biografi „A. D. Jorgensen og 1864" giver A. D. Jørgensens søn, fhv. højesteretspræsident, dr. jur. Troels G. Jorgensen, en fremstilling til belysuing af betydningen af katastrofen i $\mathbf{1 8 6 4}$ for faderen og af den påfølgende menneskealders stræben mod genforeningen. Som motto har forfatteren valgt et citat fra et brev, som A. D. Jørgensen i 1883 sendte den norske rigsarkivar M. Birkeland: „Mit livs tilskikkelse er blevet den, hver dag i det mindste een gang at føle brodden af mine særlige landsmænds tunge lod." Krigen i 1864 gjorde sønderjyden A. D. Jørgensen til historiker. Han ville udforske årsagerne til Danmarks ulykke. Den gav også anledning til en omfattende virksomhed af langtrækkende betydning, til støtte for den sønderjyske danskhed, fra 1887 gennem et nært samarbejde med H. P. Hanssen. Denne skriver således i „Et Tilbageblik“: „Intet gav mig større tryghedsfølelse under de voldsomme angreb, jeg var udsat for, end bevidstheden om, at jeg handlede $\mathrm{i}$ hans (A.D.J.) ånd og udførte de tanker, han havde indprentet mig. "7 Troels G. Jørgensen opfatter forberedelsen af denne genforening som selve den drivende kraft i faderens hele arbejde. Overalt lod han "den fædrelandske betoning træde frem". Det ligger uden for en oversigt af denne art 
at gå nærmere ind på enkelthederne. Lad mig derfor citere Lorenz Rerup, som netop har skrevet en indgående biografi af A. D. Jørgensen: „Denne biografi er på grund af sin detailrigdom en håndsrækning til enhver, der beskæftiger sig med A. D. Jørgensen, men den er ikke mere end en hândsrækning." 8

Dette udtog har holdt sig til publiceret stof, der er udgivet i bogform i hundredaret for 1864 . Skulle den lange række af artikler, der er fremkommet så mange steder, medtages, ville det sprænge rammerne. Alligevel ville noget væsentligt mangle, hvis dette forhold ikke eksempelvis blev fremhævet. Thi det er et vidnesbyrd om, at $\mathbf{1 8 6 4}$ ikke er et objektiviseret og neutraliseret årstal i Danmarkshistorien. Sáledes er 1963-årgangen $i$ mange hojskolers airsskrifter helt eller delvis viet begivenhederne omkring 1864, i flæng kan anføres årsskrifterne fra Gymnastikhøjskolen ved Viborg, Rødding Højskole, Idrætshøjskolen i Sønderborg og Vartovbogen, udgivet af Kirkeligt Samfund af 1898. Disse skrifter, der vel er beregnet på bestemte kredse og da ikke mindst ungdommen, er af ydre uanseelige, men med mange læseværdige indlæg, der afspejler opfattelser og vurderinger af $i$ dag hos forfattere af forskelligt syn. Om virkningerne af nederlaget i 1864 derom strides endnu læg og lærd.

Nederlaget, forbitrelsen og afmagten efter 1864 blev den brutale, altovervældende og uforglemmelige virkelighed for hint slægtled, der havde indviet Istedløven, mens Prøjsens konge udnæunte Bismarck til minister og for sent forstod, at I)annevirke ikke var en virkelig forsvarsstilling, men kun et digt af Carl Ploug. Tiden derefter blev kamp, politisk, socialt og folkeligt. Genrejsningen gik for sig gennem svære brydninger, fra drom og digt til selvkritik og selvtillid. Det svære, at vinde freden, lykkedes. De stromninger, der var sat i gang for 1864, viste sig at være bæredygtige, da folkets skjulte reserver forvandlede nederlaget, ikke til sejr - men til nye livsmuligheder. Sårfeberen fra Dybbøl er lægt. 


\section{HENVISNINGER:}

Efter aftale med redaktionen bringes ikke henvisninger til de citerede steder $\mathbf{i}$ den anmeldte litteratur.

1. SJy Ärb., 1. halvbind 1964, s. 11.

2. Harald Jørgensen: $\$ 1864$ - Et historisk mindeâr " i Nordisk Tidskrift för vetenskap, konst och industri, häfte 5, 1964, s. 302.

3. M. Friis Møller og Ernst Mentze: »1864 - et hundredårsminde", 1963. Litteraturlisten s. 354-357.

Et meget begrænset udvalg af litteratur om Sonderjylland findes i "Læs om Sonderjylland", udg. af Dansk Centralbibliotek for Sydslesvig i hundredåret for 1864 .

4. Se s. 304 og $\mathrm{s}$. 306 i den under note 2 næunte oversigt.

5. Afdelingsleder Karl Clausen, Sanghistorisk arkiv ved Ârhus Universitet er $\mathrm{i}$ gang med indsamling og registrering af skillingsviser og håndskrevne viser fra 1864 .

6. Se f. eks. Cai M. Woels oversigt i $* 1864$ - et hundredårsminde« s. 277-326.

7. H. P. Hanssen: »Et Tilbageblik « I, s. 214.

8. Hist $T$ (Da), 12. række, 1. binds 4. hefte, s. 522. 